\title{
Liquidity risk, credit risk, and the federal reserve's responses to the crisis
}

\author{
Asani Sarkar
}

Published online: 13 October 2009

(C) Swiss Society for Financial Market Research 2009

\begin{abstract}
In responding to the severity and broad scope of the crisis, the Federal Reserve (the Fed) has aggressively utilized both traditional monetary policy instruments, as well as innovative tools to provide liquidity. In this paper, the Fed's actions are examined in light of the evolution of risk during the crisis. The empirical evidence supports the Fed's views on the primacy of liquidity constraints in the earlier stages of the crisis and the increased prominence of counterparty credit risk as the crisis evolved in 2008. I conclude that an understanding of the prevailing risk environment is necessary to evaluate when central bank programs are likely to be effective and under what conditions the programs might cease to be necessary.
\end{abstract}

Keywords Crisis · The Federal Reserve · Liquidity facilities · Credit risk

JEL Classification $\mathrm{G} 00 \cdot \mathrm{G} 01 \cdot \mathrm{G} 10 \cdot \mathrm{G} 20$

\section{Introduction}

The economic crisis that began in 2007 has been of broad scope, severely affecting many markets and diverse institutions. ${ }^{1}$ The crisis started with declines in US housing prices and the associated rise in delinquencies on subprime mortgages. Since the expansion of subprime mortgages was only part of a much larger credit boom, other forms of credit were soon affected. Due to the complex nature of the credit instruments and the opacity of their markets, investors became increasingly uncertain about

\footnotetext{
${ }^{1}$ Acharya and Richardson (2009), Adrian and Shin (2009), Brunnermeier (2009), Gorton (2008), and Blanchard (2009), among others, describe the genesis of the crisis and provide explanations for how it was propagated.
}

\section{A. Sarkar $(\bowtie)$}

The Federal Reserve Bank of New York, 33 Liberty Street, New York, NY 10045, USA

e-mail: asani.sarkar@ny.frb.org 
the magnitude and location of the risks underlying these instruments. They reacted by becoming more risk averse and either stopped trading or asked for substantially higher compensation to take on risk. A broad range of asset markets, such as those for securitized products, became impaired. Financial institutions dependent on these markets suffered losses on their investments and cut back on their lending. The crisis became more acute in September 2008 when the failure or near failure of major financial firms resulted in financial markets freezing up.

In responding to the multidimensional nature of the crisis, the Federal Reserve (the Fed) has aggressively utilized both traditional monetary policy instruments as well as innovative tools to provide liquidity. During the initial phase of the crisis, the Fed substantially reduced the target for the federal funds rate. These actions helped bring down lending rates, especially at the short end. However, credit markets remained dysfunctional as traditional funding sources for financial institutions and markets had dried up. Thus, the Fed expanded its toolkit and reached beyond its traditional monetary policy instruments.

Why did the Fed need to implement nontraditional liquidity provision mechanisms? Normally, the Fed provides reserves to a small number of primary dealers who distribute these reserves to banks via the interbank market; in turn, banks lend to ultimate borrowers. When the market is disrupted, the Fed uses the discount window facility to provide short-term backup funding to eligible depository institutions. ${ }^{2}$ In the current crisis, interbank markets were dysfunctional, especially for term lending, and banks were reluctant to borrow from the discount window, perhaps in part due to the "stigma" associated with such borrowing. ${ }^{3}$ Thus, the Fed utilized auction mechanisms to encourage participation by banks (e.g., the Term Auction Facility (TAF) auctioned credit to eligible depository institutions for terms up to 84 days). Since credit intermediation by banks was impaired, the Fed expanded the pool of borrowers it typically lends to (e.g., to primary dealers via the Primary Dealer Credit Facility (PDCF) program). The Fed also assisted borrowers in specific markets (e.g., the collateralized funding markets through the Term Securities Lending Facility (TSLF)). ${ }^{4}$

The Fed's nontraditional liquidity tools are, by now, large in number and address a variety of markets and financial institutions (Fig. 1). These tools have been introduced sequentially in response to the evolution of risk as the crisis proceeded apace. Their common element is that each involves the Fed's authority to extend credit or purchase securities. Bernanke (2009) describes the stages of the Fed's responses. The first stage involved the provision of short-term liquidity to sound financial institutions, in line with the Fed's traditional role of lender of last resort (LOLR). Examples

\footnotetext{
${ }^{2}$ Flannery (1996) shows that private loan markets can fail because lenders become less certain how to distinguish between illiquid and insolvent banks. He advocates unsecured discount window (DW) lending at subsidized rates (i.e., below the rate required by a lender who "pools" insolvent and illiquid banks). Goodfriend and King (1988) contend that central banks should never lend to individual banks as doing so is more likely to lend to insolvent than to illiquid banks and thereby reduces market discipline.

${ }^{3}$ For example, Furfine (2003) shows evidence consistent with potential borrowers staying away from the discount window, perhaps out of concern that such borrowing will be viewed as a sign of higher credit risk.

${ }^{4}$ See Armantier et al. (2008), Adrian et al. (2009), and Fleming et al. (2009) for descriptions of TAF, PDCF, and TSLF, respectively. For descriptions of other Fed programs, see http://www.federalreserve.gov/ monetarypolicy/bst.htm.
} 


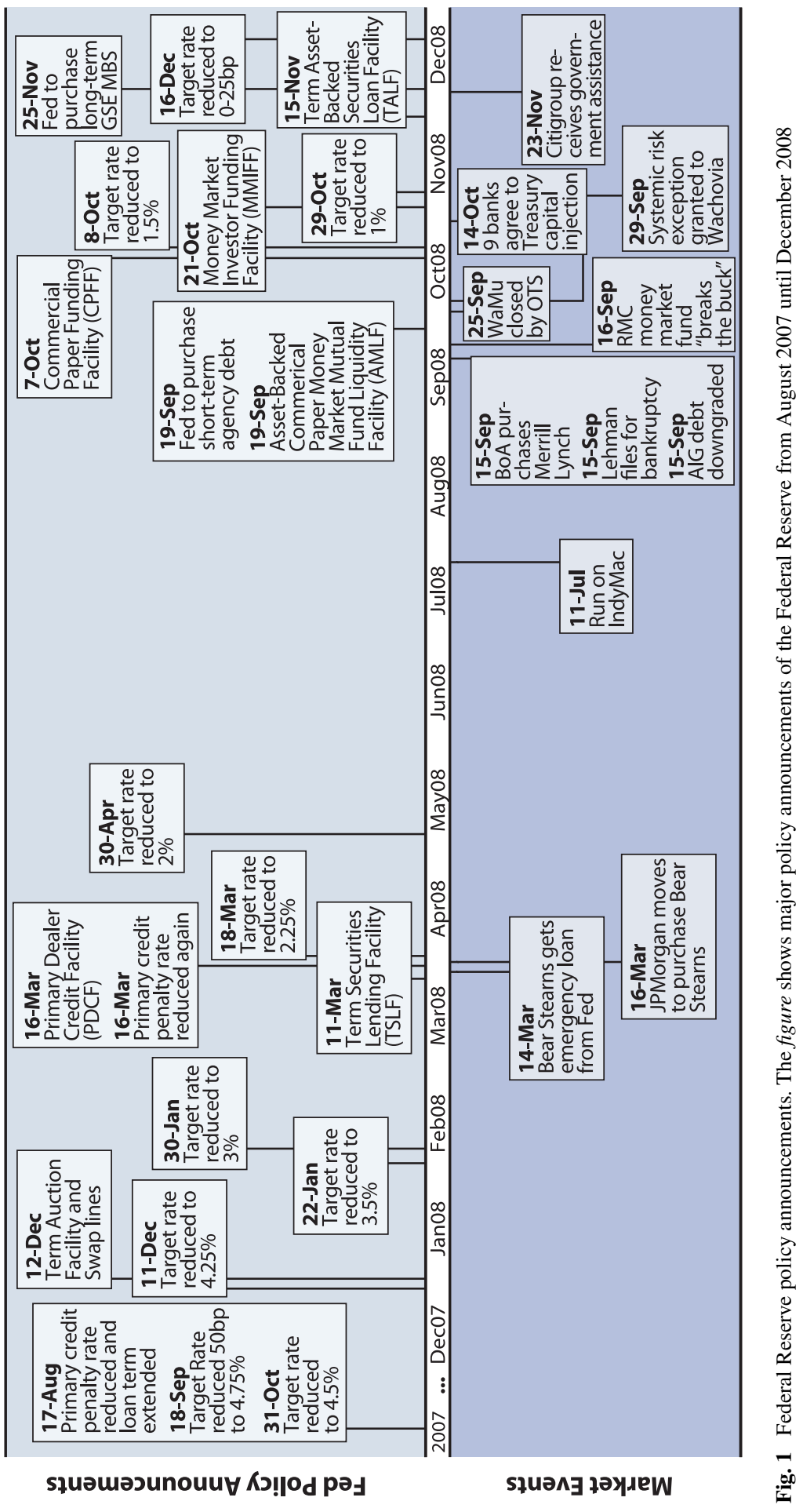


of the first stage programs are the TAF and bilateral currency swap arrangements with international central banks, allowing the latter to provide dollars to banks in their own jurisdictions. A second set of policy tools involved the provision of liquidity directly to borrowers and investors in key credit markets. An example of the second stage programs is a facility to purchase highly rated commercial paper at a term of three months. The final set of policy tools involves the purchase of longer-term securities for the Fed's portfolio. For example, the Fed announced plans to purchase mortgagebacked securities (MBS) of government-sponsored enterprises (GSEs).

In the remainder of the paper, I examine the logic and timing of the introduction of the Fed's liquidity programs, particularly the Stage 1 and Stage 2 programs, in light of the risk environment prevailing during the crisis at each stage. I selectively review the appropriate literature, emphasizing those papers that have policy relevance for the current crisis. Finally, I review the empirical evidence on how liquidity constraints and credit risk measures determined asset prices as the crisis evolved, and the effectiveness of the Fed's programs in reducing liquidity constraints at various stages of the crisis. I end with a summary of the results.

\section{Rationale of the Fed's responses to the crisis}

What is the rationale behind the Fed's introduction of certain programs at certain times? In Sect. 2.1, I discuss first-stage programs (which are extensions of the Fed's traditional role of LOLR). The focus is on the balance sheet mechanism, which states that an initial fall in asset prices causes balance sheet constraints to tighten, leading to distress sales and further reductions in asset prices. Central banks appear well placed to mitigate funding constraints as the LOLR; indeed, Bernanke (2009) emphasizes the balance sheet effects of the crisis. ${ }^{5}$ In Sect. 2.2, the second-stage programs (which target stressed credit markets and the borrowers therein) are discussed focusing on the role of asymmetric information and counterparty credit risk.

\subsection{The Fed's stage 1 programs}

The Fed's programs during the first stage of the crisis were introduced between December 2007 and March 2008 (see the top panel of Fig. 1). These programs were aimed toward improving aggregate liquidity and, also, the distribution of liquidity across financial intermediaries. Aggregate liquidity was enhanced by reductions in the federal funds target rate by a cumulative 325 basis points between September 2007 and April 2008. In comparison, the objective of the new liquidity programs was to improve the allocation of liquidity across financial institutions (i.e., primary dealers and depository institutions). For example, the TAF program was intended to "ensure that liquidity provisions can be disseminated efficiently even when the unsecured inter-bank markets are under stress". 6 The TAF achieved this objective by

\footnotetext{
${ }^{5}$ Other examples of amplification mechanisms are the maturity mismatch between assets and liabilities (Diamond and Dybvig 1983) and Knightian uncertainty (Krishnamurthy 2009a; Pritsker 2009).

${ }^{6}$ Emphasis added. See Federal Reserve Board Press Release (December 12, 2007).
} 
using an auction mechanism to provide liquidity to depository institutions with the greatest needs (McAndrews et al. 2009).

What are the anticipated benefits of these measures? Bernanke (2009) outlines two potential gains. Since banks typically fund long-term assets with short-term money, a loss of confidence would force them to engage in a fire sale of assets. ${ }^{7}$ By providing a liquidity backstop, this potential fire sale is avoided. In other words, the Fed's objectives were to mitigate the propagation of the crisis through the balance sheet channel. ${ }^{8}$ Shleifer and Vishny (1997) show how negative shocks are amplified if investors withdraw money from funds. They assume that fund managers can invest in one risky asset over three periods. If the asset has a negative "sentiment" shock in the interim period, fund managers experience investor outflows that amplify the original sentiment shock. Gromb and Vayanos (2002) study arbitrageurs who put a convergence trade across two segmented markets and face margin constraints (derived endogenously as in Geanakoplos 2003) in each market. When arbitrageur capital is scarce, negative shocks to capital induce arbitrageurs to liquidate their positions. This widens the price discrepancy that arbitrageurs are trading against, thus reducing market liquidity, and further depletes arbitrageur capital. In Brunnermeier and Pedersen (2009), the margin requirement depends on expected price volatility and (in equilibrium) the actions of constrained agents. The authors demonstrate a "margin spiral" whereby higher volatility leads to tighter constraints, triggers distress sales, and further increases in volatility. ${ }^{9}$

In the context of this literature, the Fed's Stage 1 programs may be viewed as easing balance sheet constraints and thereby breaking the illiquidity spiral (Krishnamurthy 2009a). A good example is the TSLF program, which allows dealers to swap illiquid securities (say, MBS) for liquid Treasury securities that they can subsequently use as collateral and pay a lower margin on borrowed funds. As evidence of the effectiveness of this program, the spread between agency MBS repo rates and the general collateral (GC) repo rates decreased after the TSLF program was implemented (Fig. 2). Fleming et al. (2009) show this reduction to be statistically significant. Since the repo spread may be attributed to the reduced collateral value (from greater illiquidity) of MBS relative to Treasuries, its reduction suggests a loosening of margin constraints. More generally, the Fed restarts funding markets and liquefies frozen balance sheets by charging a lower rate on collateralized funds than the private market or by providing secured lending when private agents are unwilling to do so. ${ }^{10}$

\footnotetext{
${ }^{7}$ Allen et al. (2009) provide another rationale for central bank intervention. When markets are incomplete, they show that the price of the long-lived asset may exhibit excessive price volatility. By using open market operations appropriately to fix interest rates, the central bank can prevent price volatility and implement the constrained efficient solution. Thus, the central bank effectively completes the market, and open-market operations are sufficient to deal with systemic liquidity crises.

${ }^{8}$ The feedback between firms' balance sheets, asset prices, and the macroeconomy is discussed in Bernanke (1983), Bernanke and Gertler (1990), and Mishkin (1991).

${ }^{9}$ Margin constraints are one (perhaps the most common) example of a balance sheet constraint. Another example is constraints whereby lenders limit the debtor's investments based on pledged collateral (Kiyotaki and Moore 1997). In He and Krishnamurthy (2008), incentive conflicts limit the amount of coinvestment by outsiders in a mutual fund.

${ }^{10}$ Traditional LOLR policies advocate lending to solvent institutions against good collateral at a penalty rate (Rochet and Vives 2004). However, Cecchetti and Disyatat (2009) argue that when there is generalized
} 


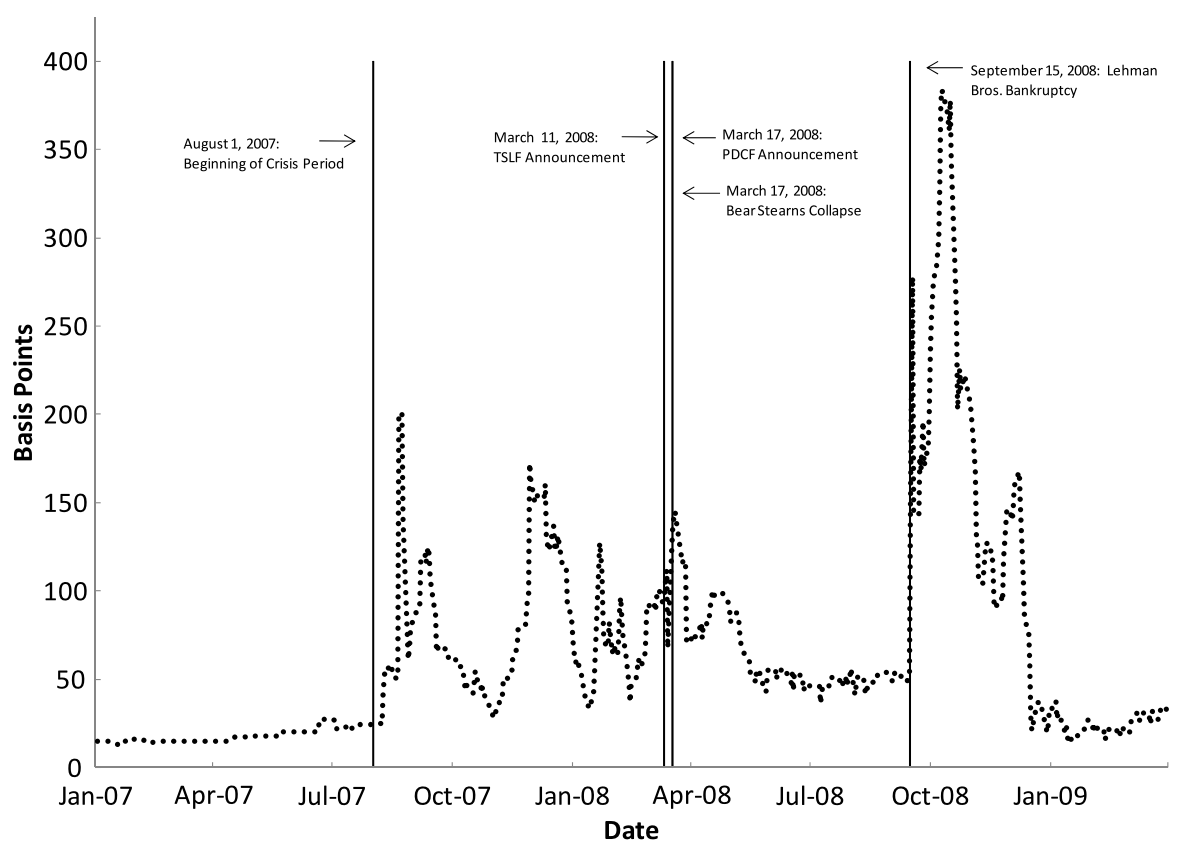

Fig. 2 Agency MBS-GC repo spread and federal reserve liquidity programs. The figure plots the 1-month Agency MBS minus GC repo spread and announcement dates of the Federal Reserve's Term Securities Lending Facility (TSLF) and the Primary Dealer Credit Facility (PDCF) programs. The sample period is from January 1, 2007, until March 30, 2009

The Fed is able to do so because, as a patient investor, it requires a lower liquidity risk premium than do private lenders.

A second benefit mentioned by Bernanke (2009) is that reducing the funding stress makes banks more likely to lend. Benmelech and Bergman (2009) provide a rationale for aggressive central bank lending when banks restrict lending. They assume that banks cannot commit to repay their loans because of agency problems or incomplete contracts so that lending is determined solely by collateral value. A decline in collateral value results in lower lending, leading to lower corporate liquidity; in turn, this leads to even lower collateral value since firms are less able to purchase assets. ${ }^{11}$ In the "jump start" equilibrium, a small injection of reserves by central banks induces banks to hoard liquidity since the anticipated rise in collateral value is too small to justify lending; hence the need for forceful lending.

Heider et al. (2009) build a model of interbank markets in the spirit of Diamond and Dybvig (1983). The interbank market distributes liquidity from banks with ex-

market failure, it may not make sense to provide liquidity at a penalty rate over the market since no particular institution is benefiting relative to others. They conclude that "liquidity support will often, and probably should, be provided at a subsidized rate when it involves an illiquid asset where a market price cannot be found".

${ }^{11}$ Thus, the model builds on Holmstrom and Tirole (1997) by allowing the liquidation value to be endogenous. 
cess liquidity to those with a liquidity shortage. Counterparty risk exists since the long-term investment is risky and the interbank loan may not be repaid. The authors introduce asymmetric information about counterparty risk and show that the interbank market exhibits different regimes depending on the level and dispersion of counterparty risk. While the interbank market performs smoothly in one regime, in another it becomes dysfunctional as either safer borrowers drop out or lenders hoard liquidity (despite high interest rates). The central bank intervenes by providing liquidity to risky banks at reduced interest rates, at the cost of crowding out the private supply of liquidity. ${ }^{12}$

An alternative explanation (to asymmetric information) for liquidity hoarding arises if banks fear they will be unable to finance projects and trading strategies due to uncertainty in the aggregate demand for liquidity (Allen et al. 2009). In such a case, central bank intervention may be unnecessary since banks hold sufficient liquidity to meet their own needs without accessing the interbank markets (Allen and Carletti 2008).

\subsection{The Fed's stage 2 programs}

The first-stage programs exposed the Fed to minimal credit risk. The Fed's loans to banks and primary dealers through the various facilities are overcollaterized and made with recourse to the borrowing firm. ${ }^{13}$ In the case of the currency swap lines, the foreign central banks are responsible for payments; moreover, the Fed receives an equivalent amount of foreign exchange for the dollars it provides to the central banks.

As the crisis continued to evolve, concern about the credit risk of financial institutions and bank capital increased. The Fed's Stage 1 programs were dependent on solvent institutions that could intermediate the flow of credit from the Fed to the economy. As these intermediaries became impaired themselves, they were increasingly unwilling to lend. In addition, certain credit markets (such as commercial paper (CP)) became particularly afflicted. Consequently, the Fed decided to lend directly to some affected borrowers and markets-its second-stage programs.

The Fed's second-stage programs were designed to provide liquidity in a targeted manner to borrowers and investors in key credit markets (Bernanke 2009). These programs were rolled out in September 2008 (top panel of Fig. 1). The programs came in two flavors. Continuing its LOLR role, the Fed provided a liquidity backstop to money market mutual funds (MMMF) and to CP borrowers. The Fed developed

\footnotetext{
${ }^{12}$ Flannery (1996) also studies asymmetric information problems and identifies a "winner's curse" problem facing new lenders in banking markets (see footnote 2). There is a vast literature on central bank or government intervention to address market failures in the face of asymmetric information, moral hazard, and monopoly power. Holmstrom and Tirole (1998) and Diamond and Rajan (2005) analyze the optimal (public) provision of liquidity when interbank markets face aggregate liquidity shocks and contagious failures generated by the illiquidity of bank assets. Gorton and Huang (2006) rationalize the LOLR function of central banks by the need to monitor banks and provide them with liquidity during crises in order to prevent inefficient panics. Acharya et al. (2008) examine how the strategic power of an interbank lender might force a liquidity-constrained borrower to sell at fire sale prices. The strategic power is the market failure that justifies central bank intervention.

${ }^{13}$ For a description of the required collaterals, see http://www.federalreserve.gov/monetarypolicy/ bst_ratesetting.htm.
} 
a facility to finance bank purchases of high-grade asset-backed CP from MMMFs, which helped the latter meet redemption demands without having to sell assets at distress prices. Another Fed facility was to buy high-quality (A1-P1) CP at a term of 3 months, which reduced the risk that $\mathrm{CP}$ borrowers could not rollover maturing issues.

The second flavor of Fed programs went beyond providing liquidity and addressed the capital needs of borrowers in select asset-backed markets. In a joint effort with Treasury, the Term Asset-Backed Securities Loan Facility (TALF) provides 3-year or 5-year term loans to investors against (mostly) new issuances of AAA-rated securities. With the Treasury providing capital, this facility allows the Fed to accept a certain amount of credit risk. The Fed manages the credit risk by appropriate selection of haircuts on the collateral put up for the loans. The objective of the program is to revive private lending by enabling lenders to securitize new loans. In addition, by stimulating market activity, the facility potentially increases the valuation of existing loans by reducing the illiquidity premium.

Bolton et al. (2009) analyze a model with private and public provision of liquidity in the presence of asymmetric information about financial intermediary assets. ${ }^{14}$ They show that public liquidity can complement private liquidity when the adverse selection problem is so severe that markets break down without public support. The central bank guarantees a minimum price for assets by lending against collateral. Such a policy helps decrease the incentives of financial institutions to rely on their cash balances ("inside" liquidity) and, in turn, increases the availability of "outside" liquidity from long-horizon investors. The latter also benefit from being able to buy valuable long-term assets at a reasonable price by borrowing from the central bank.

\section{Effectiveness of the Fed's programs: empirical evidence}

Implicit in the timing of the Fed's responses is a view of the evolution of risk as the crisis progressed. In particular, the Fed's Stage 1 programs emphasized the provision of liquidity to solvent institutions, implying that at this early stage of the crisis the Fed viewed illiquidity, rather than credit, as the greater risk to the economy. In contrast, the second-stage programs reflected the Fed's views of the increasing importance of credit risk.

McAndrews (2009) investigates extreme divergence in rates during the crisis between LIBOR and the fed funds markets, which are normally closely related. Such divergences may persist if arbitrageurs lack capital to take advantage of the oppor-

\footnotetext{
${ }^{14}$ Bolton et al. (2009) builds on the literature that integrates financial intermediaries and securities markets in a single framework. In Diamond (1997), banks coexist with securities markets since households face costs in switching between banks and securities markets. Fecht (2004) introduces segmentation on the asset side between financial intermediaries' investments in firms and claims issued directly by firms to investors though securities markets. Allen and Gale (2004) introduce securities markets into a general equilibrium theory of institutions. Intermediaries provide liquidity insurance, as in Diamond and Dybvig (1983), and risk-sharing services by packaging existing claims for investors without access to markets. The financial system is efficient as long as markets are complete.
} 


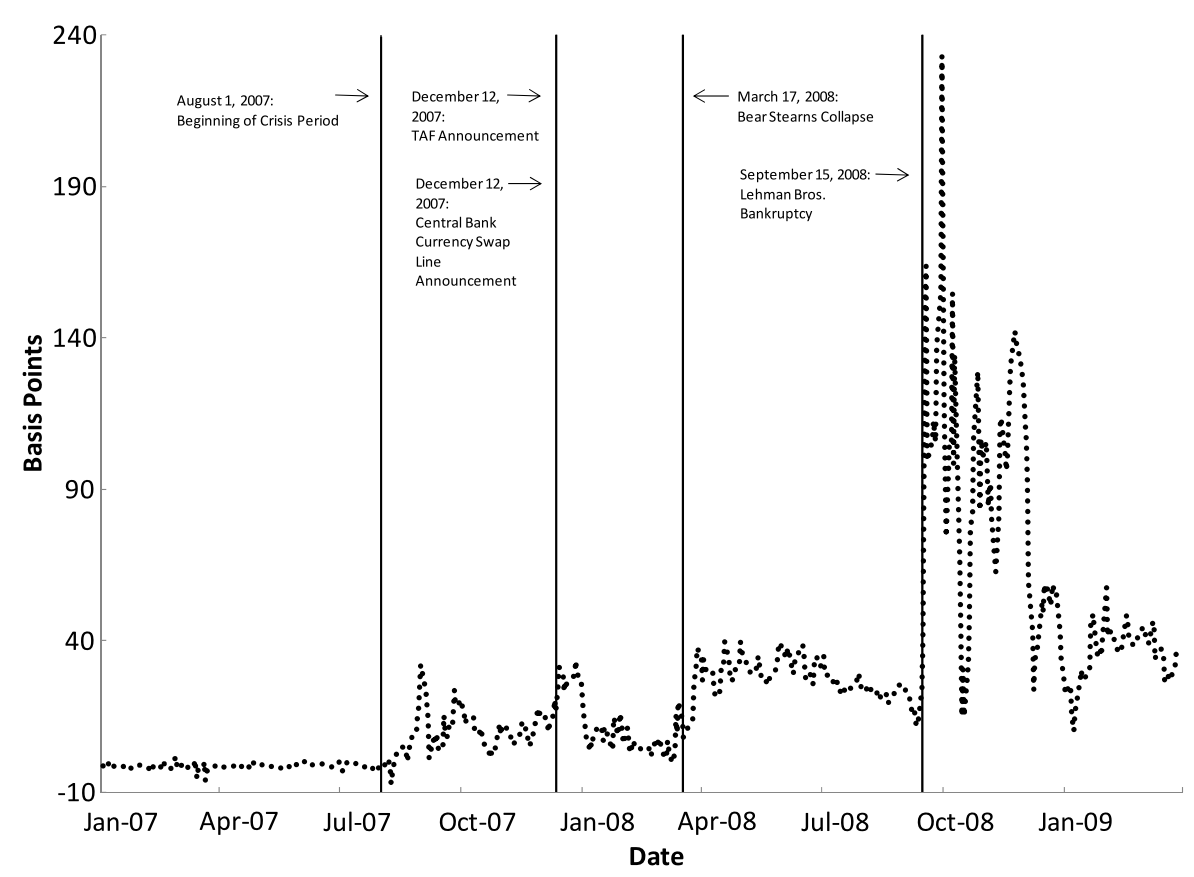

Fig. 3 Deviations from covered interest rate parity, January 2007-March 2009. The figure plots estimates of deviations from Covered Interest Rate Parity (CIP) in US dollars, estimated using the euro-dollar spot and forward exchange rates and the euro LIBOR rate. The sample period is from January 1, 2007, until March 30, 2009

tunity (Shleifer and Vishny 1997). ${ }^{15}$ Consistent with the idea that capital constraints were binding, McAndrews (2009) shows how the Fed moderated the divergence by supplying dollars through currency swap lines (Table 1).

Coffey et al. (2009) show substantial and persistent deviations from the covered interest parity (CIP) condition during the crisis (Fig. 3). Such deviations represent an arbitrage opportunity involving lending US dollars and borrowing in another currency. Coffey et al. (2009) study the determinants of CIP deviations and show that tighter margin conditions are positively associated with CIP deviations prior to the Lehman bankruptcy, except during the period when the Fed eased margin conditions via its TSLF program. Moreover, the Fed's supply of dollars (through currency swap lines and TAF) reduced CIP deviations during this period (Table 1). These findings are consistent with limits to arbitrage in the foreign exchange and international money markets due to capital constraints, which were eased by the Fed's supply of dollars. Alternatively, the arbitrage trade may have suddenly turned risky as previously lowrisk trading counterparties became insolvent. Indeed, after the Lehman bankruptcy, counterparty risk and its dispersion (an important variable in Heider et al. 2009) became important determinants of CIP deviations and the Fed's supply of dollars was

\footnotetext{
${ }^{15}$ Garleanu and Pedersen (2009) and Krishnamurthy (2009b) also study instances of deviations from the Law of One Price and how limits to arbitrage prevented the arbitrage opportunities from being exploited.
} 


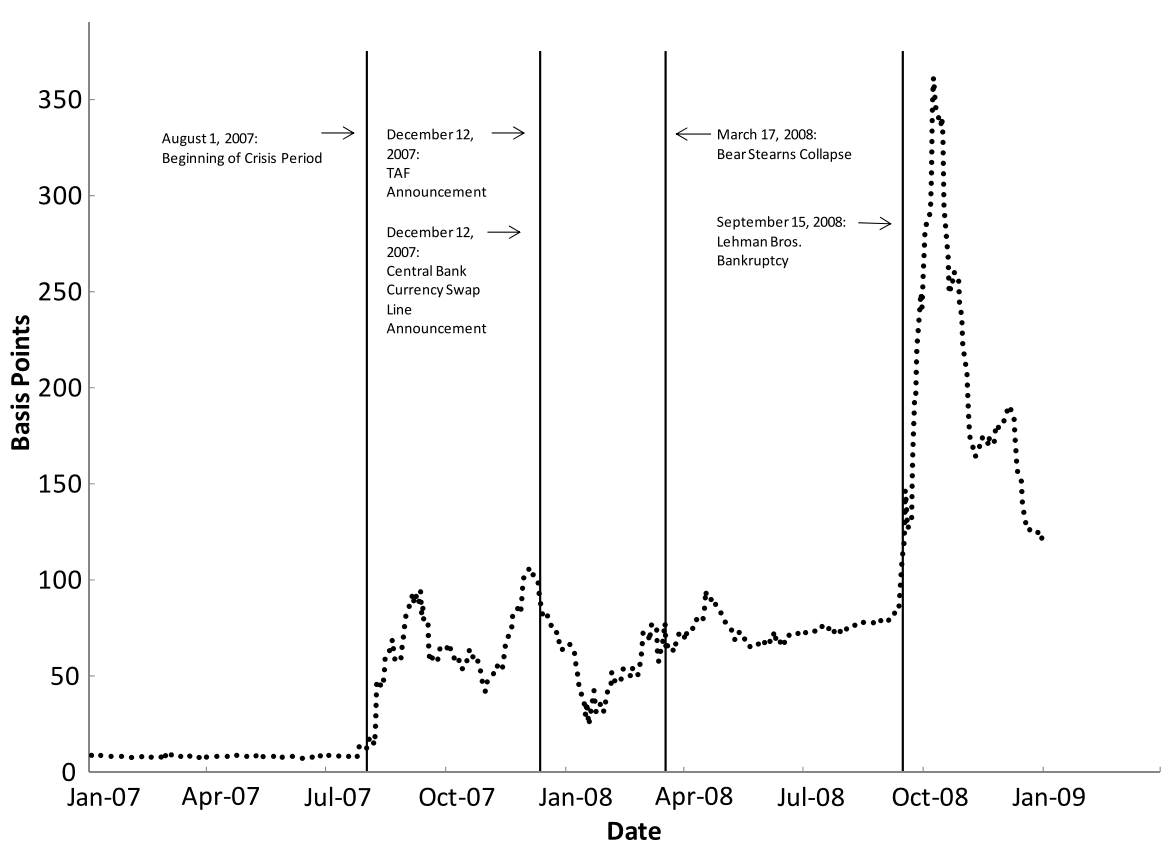

Fig. 4 LIBOR-OIS spread, January 2007-March 2009. The figure plots the difference between LIBOR and OIS rates for the 3-month maturity in US dollars (USD). The sample period is from January 1, 2007, until March 30, 2009

less effective in reducing the deviations. In general, these results indicate that both liquidity and credit risks are responsible for the failure of arbitrage, but that the contribution of each has varied over time.

The LIBOR rate minus the overnight indexed swap (OIS) rate, or the LIBOROIS spread, is a popular measure of stress in the interbank market during the crisis. LIBOR is a benchmark unsecured interbank interest rate published by the British Bankers Association (BBA). OIS represents the expected average of the overnight fed funds rate over the term of the loan. Arbitrage should normally ensure that the spread is close to zero. ${ }^{16}$ However, this spread has widened during the crisis (Fig. 4).

McAndrews et al. (2009) decompose the LIBOR-OIS spread into its credit risk and noncredit risk components for the period January 2007 to April 2008. They find that the noncredit risk component was the major part of the LIBOR-OIS spread in 2007. The credit risk component of the spread was high and volatile in 2008. However, since the credit default swap (CDS) market became highly illiquid at this time, part of the credit risk component is likely to reflect liquidity risk as well. Consistent with the importance of liquidity risk, McAndrews et al. (2009) find that the Fed's liquidity provision through the TAF program significantly reduced the LIBOR-OIS spread during their sample period (Table 1).

\footnotetext{
${ }^{16}$ The two legs of the arbitrage are: loan $\$ \mathrm{X}$ for (say) 3 months; then fund the loan by borrowing $\$ \mathrm{X}$ each day in the fed funds market and, finally, hedge the interest rate risk by purchasing an OIS contract (Gorton and Metrick 2009).
} 
Table 1 Effectiveness of federal reserve liquidity programs

\begin{tabular}{|c|c|c|c|}
\hline Paper & Metric & Program & Effective? \\
\hline $\begin{array}{l}\text { Fleming et al. } \\
(2009)\end{array}$ & $\begin{array}{l}\text { Repo spread } \\
\text { between Treasury } \\
\text { collateral and } \\
\text { lower quality } \\
\text { collateral }\end{array}$ & TSLF & Yes \\
\hline $\begin{array}{l}\text { McAndrews } \\
(2009)\end{array}$ & $\begin{array}{l}\text { Divergence } \\
\text { between LIBOR } \\
\text { and Fed funds }\end{array}$ & $\begin{array}{l}\text { Central Bank } \\
\text { currency swap } \\
\text { lines and TAF }\end{array}$ & Yes \\
\hline $\begin{array}{l}\text { Coffey et al. } \\
(2009)\end{array}$ & $\begin{array}{l}\text { Deviation from } \\
\text { Covered Interest } \\
\text { Rate Parity }\end{array}$ & $\begin{array}{l}\text { Central Bank } \\
\text { currency swap } \\
\text { lines and TAF }\end{array}$ & $\begin{array}{l}\text { - Yes, before } \\
\text { Lehman } \\
\text { bankruptcy } \\
\text { - No, after } \\
\text { Lehman } \\
\text { bankruptcy }\end{array}$ \\
\hline $\begin{array}{l}\text { McAndrew et al. } \\
(2009)\end{array}$ & $\begin{array}{l}\text { Divergence } \\
\text { between LIBOR } \\
\text { and OIS rates }\end{array}$ & TAF & $\begin{array}{l}\text { Yes (sample ends } \\
\text { April 2008) }\end{array}$ \\
\hline
\end{tabular}

The table reports results from papers (listed in the order they are discussed in the text) evaluating various liquidity facilities of the U. S. Federal Reserve

The literature discussed so far acknowledges that yield spreads are likely composed of both liquidity and credit risks. An alternative view is that spreads are entirely, or primarily, reflective of counterparty credit risk. Taylor (2009), for example, asserts that the LIBOR-OIS spread primarily reflects credit risk. As evidence, he interprets the LIBOR-GC repo spread as a measure of counterparty credit risk and points to the high correlation between the LIBOR-GC and LIBOR-OIS spreads. However, since LIBOR is common to both spreads, it is not clear whether the high correlation is indicative of a significant economic relationship. Moreover, as Garleanu and Pedersen (2009) show, the spread between an unsecured and secured rate, such as the LIBOR-GC repo spread, is in equilibrium the shadow cost of capital for margin-constrained investors and hence is correlated with liquidity risk.

As further support for the view that counterparty risk drove the crisis, Taylor (2009) cites the evidence in Taylor and Williams (2009) that TAF had no effect in reducing the LIBOR-OIS spread. Taylor and Williams (2009), however, do not directly test the efficacy of TAF since they ignore TAF announcement effects and include only the auction and settlement dates. Auction and settlement dates are scheduled ahead of time and contain little information content, so it is not surprising that the LIBOR-OIS spread is not impacted on these days. ${ }^{17}$

In summary, the evidence indicates that the LIBOR-OIS spread and other indicators of crisis severity, such as deviations from CIP, likely reflect both liquidity and credit risk in time-varying proportion. Moreover, the risk environment appears to have evolved from capital and liquidity shortages in the early part of the crisis

\footnotetext{
${ }^{17}$ Another reason to question the result in Taylor and Williams (2009) is that they use the level of the spread rather than its change even though the LIBOR-OIS spread has a unit root.
} 
to credit risk in the latter part. Therefore, the results are generally supportive of the Fed's views of the main risks facing the economy at different times. In particular, the Fed introduced TAF and the bilateral currency swap lines in December 2007 and the TSLF and the PDCF in March 2008. All these programs were designed primarily to address liquidity risk. No further programs were introduced by the Fed between April and August 2008. As movements in credit risk became a dominant feature of financial markets starting in August 2008, the Fed introduced programs, such as the TALF, that addressed mitigation of both credit and liquidity risk.

\section{Conclusion}

The ongoing economic and financial crisis has caused large reductions in asset prices, in new issuances of primary securities, and affected a variety of markets and institutions. In responding to the multidimensional nature of the crisis, the Federal Reserve has aggressively utilized both traditional monetary policy instruments as well as innovative tools to provide liquidity. In this paper, I elaborate on the logic and the timing of introduction of the Fed's liquidity programs. I examine the Fed's actions in light of the underlying financial amplification mechanisms responsible for propagating the crisis (in particular, balance sheet constraints and counterparty credit risk). The empirical evidence supports the Fed's views on the primacy of liquidity risk in the earlier stages of the crisis and the subsequent prominence of credit risk as the crisis evolved in 2008.

An examination of how risk evolved during the crisis leads to a nuanced view of the key forces driving the crisis. If credit risk is the only driver of the crisis, then the Fed has been "barking up the wrong tree" by addressing liquidity concerns and its programs, almost by definition, are bound to prove ineffective. On the other hand, if liquidity is the dominant risk in all stages of the crisis, then the Fed's liquidity facilities should be effective at all times. However, the analysis shows that liquidity and credit risks have both been important, but at different stages of the crisis and to different degrees. The Fed's programs were effective when lack of liquidity was driving asset prices and less so when counterparty credit risk became dominant. Therefore, having a clear idea of the "risk context" is necessary to understand when central bank programs are likely to be effective and under what conditions the programs might cease to be so.

Acknowledgements I thank the anonymous referee(s) for valuable comments. I am grateful to Lauri Feldman and Jeffrey Shrader for excellent research assistance. The views stated here are my own and do not necessarily reflect the views of the Federal Reserve Bank of New York or the Federal Reserve System.

\section{References}

Acharya, V., Richardson, M. (eds.) Restoring Financial Stability: How to Repair a Failed System. Wiley, New Jersey (2009)

Acharya, V., Gromb, D., Yorulmazer, T.: Imperfect competition in the inter-bank market for liquidity as a rationale for central banking. Working Paper, London Business School (2008) 
Adrian, T., Shin, H.: The changing nature of financial intermediation and the Financial Crisis of 20072009. Annu. Rev. (2009, forthcoming)

Adrian, T., Burke, C., McAndrews, J.: The federal reserve's primary dealer credit facility. Curr. Issues Econ. Finance 15, 4 (2009)

Allen, F., Carletti, E.: The role of liquidity in financial crises. In: Maintaining Stability in a Changing Financial System, Proceedings of the 2008 Jackson Hole Conference, Federal Reserve Bank of Kansas City (2008)

Allen, F., Gale, D.: Financial intermediaries and markets. Econometrica 72(4), 1023-1061 (2004)

Allen, F., Carletti, E., Gale, D.: Interbank market liquidity and central bank intervention. J. Monet. Econ. 56(5), 639-652 (2009)

Armantier, O., Krieger, S., McAndrews, J.: The federal reserve's term auction facility. Curr. Issues Econ. Finance 14, 5 (2008)

Bernanke, B.: Nonmonetary effects of the financial crisis in the propagation of the great depression. Am. Econ. Rev. 73, 257-276 (1983)

Bernanke, B.: The crisis and the policy response. The Stamp Lecture of the London School of Economics, London, England (2009)

Bernanke, B., Gertler, M.: The financial accelerator in a quantitative business cycle framework. Q. J. Econ. 105, 87-114 (1990)

Benmelech, E., Bergman, N.: Credit traps. Working Paper, Harvard University and MIT (2009)

Blanchard, O.: The crisis: basic mechanisms, and appropriate policies. IMF Working Paper WP/09/80 (2009)

Bolton, P., Santos, T., Scheinkman, J.: Inside and outside liquidity. NBER Working Paper No. 14867 (2009)

Brunnermeier, M.: Deciphering the 2007-2008 liquidity and credit crunch. J. Econ. Perspect. 23(1), 77100 (2009)

Brunnermeier, M., Pedersen, L.: Market liquidity and funding liquidity. Rev. Financ. Stud. 22(6), 22012238 (2009)

Cecchetti, S.G., Disyatat, P.: Central bank tools and liquidity shortages. Econ. Policy Rev. (2009)

Coffey, N., Hrung, W., Sarkar, A.: Capital constraints, counterparty risk and deviations from covered interest rate parity. Working Paper, The Federal Reserve Bank of New York (2009)

Diamond, D.: Liquidity, banks, and markets. J. Polit. Econ. 105(5), 928-956 (1997)

Diamond, D., Dybvig, P.: Bank runs, deposit insurance and liquidity. J. Polit. Econ. 91(5), 401-419 (1983)

Diamond, D., Rajan, R.: Liquidity shortages and banking crises. J. Finance 60, 615-647 (2005)

Fecht, F.: On the stability of different financial systems. J. Eur. Econ. Assoc. 2(6), 969-1014 (2004)

Flannery, M.J.: Financial crises, payment system problems, and discount window lending. J. Money Credit Bank. 28(4), 804-824 (1996)

Fleming, M.J., Hrung, W.B., Keane, F.H.: The term securities lending facility: origin, design, and effects. Curr. Issues Econ. Finance 15, 2 (2009)

Furfine, C.: Standing facilities and interbank borrowing: evidence from the federal reserve's new discount window. Int. Finance 6(3), 329-347 (2003)

Garleanu, N., Pedersen, L.H.: Margin-based asset pricing and deviations from the law of one price. Working Paper, NYU and UC Berkeley (2009)

Geanakoplos, J.: Liquidity, default and crashes: endogenous contracts in general equilibrium. In: Dewatripont, M., Hansen, L.P., Turnovsky, S.J. (eds.) Advances in Economics and Econometrics: Theory and Applications II, Econometric Society Monographs: Eighth World Congress, vol. 2, pp. 170-205. Cambridge University Press, Cambridge (2003)

Goodfriend, M., King, R.C.: Financial deregulation, monetary policy, and central banking. In: Haraf, W.S., Kushmeider, R.M. (eds.) Restructuring Banking and Financial Services in America. American Enterprise Institute for Public Policy Research, Washington (1988)

Gorton, G.: The panic of 2007. In: Maintaining Stability in a Changing Financial System, Proceedings of the 2008 Jackson Hole Conference, Federal Reserve Bank of Kansas City (2008, forthcoming)

Gorton, G., Huang, L.: Banking panics and the endogeneity of central banking. J. Monet. Econ. 53(7), 1613-1629 (2006)

Gorton, G., Metrick, A.: Securitized banking and the run on the repo. Yale ICF Working Paper No. 09-14 (2009)

Gromb, D., Vayanos, D.: Equilibrium and welfare in markets with financial constrained arbitrageurs. J. Financ. Econ. 66(2-3), 361-407 (2002)

He, Z., Krishnamurthy, A.: A model of capital and crises. Working Paper, Northwestern University (2008) 
Heider, F., Hoerova, M., Holthausen, C.: Liquidity hoarding and interbank market spreads: the role of counterparty risk. Working Paper, ECB (2009)

Holmstrom, B., Tirole, J.: Financial intermediation, loanable funds, and the real sector. Q. J. Econ. 112(3), 663-691 (1997)

Holmstrom, B., Tirole, J.: Private and public supply of liquidity. J. Polit. Econ. 106, 1-40 (1998)

Kiyotaki, N., Moore, J.: Credit cycles. J. Polit. Econ. 105(2), 211-248 (1997)

Krishnamurthy, A.: Amplification mechanisms in liquidity crises. Am. Econ. J., Macroecon. (2009a, forthcoming)

Krishnamurthy, A.: Debt markets in the crises. J. Econ. Perspect. (2009b, forthcoming)

McAndrews, J.: Segmentation in the US dollar money markets during the financial crisis. Working Paper, Federal Reserve Bank of New York (2009)

McAndrews, J., Sarkar, A., Wang, Z.: The effect of the term auction facility on the London inter-bank offered rate. Staff Reports 335, Federal Reserve Bank of New York (2009)

Mishkin, F.S.: Asymmetric information and financial crises: a historical perspective. In: Hubbard, G. (ed.) Financial Markets and Financial Crises. The University of Chicago Press, Chicago (1991)

Pritsker, M.: Informational easing: improving credit conditions through the release of information. Econ. Policy Rev. (2009, forthcoming)

Rochet, J.-C., Vives, X.: Coordination failures and the lender of last resort: was bagehot right after all? J. Eur. Econ. Assoc. 2(6), 1116-1147 (2004)

Shleifer, A., Vishny, R.W.: The limits of arbitrage. J. Finance 52(1), 35-55 (1997)

Taylor, J.B.: The financial crisis and the policy responses: an empirical analysis of what went wrong. NBER Working Paper No. 14631 (2009)

Taylor, J.B., Williams, J.C.: A black swan in the money market. Am. Econ. J., Macroecon. 1, 58-83 (2009)

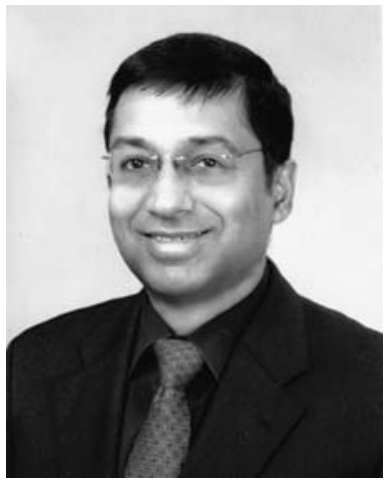

Asani Sarkar is a Research officer at the Federal Reserve Bank of New York. He is currently working on empirical evaluations of the Federal Reserve's liquidity provision programs. Dr. Sarkar has published numerous articles on the microstructure of equity, fixed income, and futures markets. His papers have appeared in, among others, the Journal of Finance, the Review of Financial Studies, the Journal of Financial and Quantitative Analysis, the Journal of Business, the Journal of Empirical Finance, the Journal of Futures Markets, and the Journal of Financial Intermediation. Dr. Sarkar received his Ph.D. from the University of Pennsylvania. 